Acta Horticulturae et Regiotecturae 1

Nitra, Slovaca Universitas Agriculturae Nitriae, 2015, pp. 5-10

\title{
BIODIVERSITY AND DYNAMICS OF OCCURENCE OF EPIGEIC GROUPS IN DIFFERENT TYPES OF FARMING
}

\author{
Jana PORHAJAŠOVÁ*, Jaroslav NOSKOVIČ, Alena RAKOVSKÁ, Mária BABOŠOVÁ, Terézia ČERYOVÁ \\ Slovak University of Agriculture in Nitra, Slovak Republic
}

\begin{abstract}
The aim of this work was to determine and compare the occurrence of epigeic groups in two methods of farming, ecological one and integrated one. The research was conducte in the locality Nitra - Dolná Malanta in the years 2013 and 2014. The monitoring locality is situated in the south-western part of Slovakia, in altitude 175-180 m on highly productive soils. For the collection of biological material, the earth traps method was applied, used during the vegetation period (from April to October), within both farming systems, at Hordeum sativum, Triticum aestivum and Vicia faba undersowing with Medicago sativa. In canopy of these crops, two soil traps were installed, renewed in monthly intervals. The total of 7,722 exemplars of epigeic groups was obtained, of which 4,355 exemplars were in ecological farming and 3,367 exemplars in integrated farming system. In both treatments, 19 epigeic groups were determined, with dominant abundance of Coleoptera, Collembola, Acarina, Araneae. Also other groups such as Diplopoda, Heteroptera, Chilopoda etc. were observed in lower occurrence. Based on the evaluation of influence of the crop in terms of the occurrence of epigeic groups, the most suitable conditions created Vicia faba with undersowing Medicago sativa (integrated farming) and Triticum aestivum (ecological farming). On the basis of calculated indexes, both farming systems can be evaluated as homeostatically balanced, providing present epigeic groups with topical and trophic conditions.
\end{abstract}

Keywords: agroecosystems, biodiversity, ecological farming, epigeic groups, integrated farming

In nature, number of changes is present, changing the structure of populations and communities of individuals. Currently, the issues of negative anthropogenic impacts that resulted in devastation and degradation of environment come to the forefront. These changes affect and disturb the equilibrium of ecosystems and largely influence/limit the existence of various groups of individuals, thereby affecting their biodiversity. Biodiversity of communities is influenced by environmental heterogeneity and correlated with the structural diversity of vegetation (Porhajašová, 2011). Zooedaphone is an important component of the biocenosis. Its presence or absence points to the burden of agroecosystems by foreign substances. Thus, it acts as an important bioindicator of the environment. Disturbed environment is deprived of this biocenosis element (Porhajašová et al., 2005). L.-Bartošová et al. (2005) and Porhajašová et al. (2008) claim in their works that the ecological stability of the landscape as a rule increases with increasing the ecosystem and species diversity. Paoletti (1999) under the term epigeon biodiversity explains that among insect (Insecta) living in the soil and on its surface, we can find representatives of many groups, for example species of orders Heteroptera, Neuroptera, Diptera, Larvae, but especially species of order Coleoptera, according to Lenoir and Lennartsson (2010) these are groups typical for agroecosystems. Strašiov et al. (2012) paid attention to the occurrence of chilopodecenosis in terms of conservation of biodiversity of their communities in agricultural land, and found out that the application of various forms of management and variety spatial distribution of small-scale agricultural areas positively affect their biodiversity. In practical study of soil fauna there are mainly species of the family Staphylinidae and Carabidae, from the order Coleoptera and species of the family Formicoidea from order Hymenoptera. Porhajašová et al. (2012) add that all present edaphic groups are involved in maintaining the nature balance, cycle of matter and energy flow in ecosystems.

In agriculture, the alternative forms of farming, which use agri-environment measures are increasingly promoted and applied. These are close to the nature and respect the broader ecological patterns, called agrienvironment agriculture, which allows long-term land use while maintaining soil fertility, puts emphasis on production, but also to maintain, or increase reasonable diversity of agroecosystems, which positively affects the occurrence and the importance of present edaphic groups. During its evolution, the present populations of edaphic groups in various stages of their growth, adapted especially in the direction of dependency on the soil type and soil class, plays an important role in $\mathrm{pH}$ of soil. We need to mention cultivation of soil and the introduction of organic and inorganic substances into the soil, many of which are toxic for these populations, resulting in decreasing the incidence of these populations (Vician et 
al., 2007; Vician et al., 2011). Šustek (1983) believes that the limited territory, surrounding agricultural land, intensive agriculture act as the main attribute which affects the appearance of geobiocoenosis. The results from three years long research Petřvalský et al. (2003) showed that organic system of farming practiced the conventional cultivation without the use of chemical fertilizers, with the application of livestock manure, with use of no pesticides, applying only mechanical and physical methods in plant protection accounted for biodiversity in the most accepted conditions of agroecosystems, evidence which is also calculated by diversity index (1.23), which is comparable to the index of diversity in nature reserves.

The aim of this study is to investigate and compare the structure of epigeic groups depending on the type of farming (ecological and integrated farming system). On the basis of calculated indicators and indexes, the appropriateness of monitored agro-ecosystems is evaluated.

\section{Material and methods}

\section{Adopted method of collection}

Epigeic material are collected by the earth traps method (1 liter glass jars with a diameter of estuary $95 \mathrm{~mm}$, to onethird with $4 \%$ formalin were filled and protected by the roof top). At the beginning of the growing season the earth traps were exposed, regularly at monthly intervals were taken out and subsequently renewed until the end of the growing season - earth traps were based on 6 May 2013 and then renewed on monthly basis: 7 June 2013, 1 July 2013, 22 July 2013, 26 August 2013, 30 September 2013, 25 October 2013. In the year 2014, the earth traps were based on 3 May 2014 and then renewed on monthly basis: 16 June 2014, 10 July 2014, 7 August 2014, 8 September 2014, 26 September 2014, 15 October 2014. The obtained biological material was determined in the appropriate taxonomic categories in terms of the Department of Environment and Zoology. The method is used to estimate the presence and species composition of epigeic communities. The advantage of the method is the relatively high efficiency, realization and financial ease, but is dependent on the activity of the species.

\section{Characteristic of locality}

The experiment was carried out in the locality Nitra - Dolná Malanta, which is experimental base of the SUA in Nitra and belongs to the category of highly productive agriculture soil. Located at an altitude of 175-180 meters above the sea level, the climatic region is warm and humid. The main soil type is Haplic Luvisol, with moderate supply of available phosphorus, high content of available potassium and good content of accessible magnesium; soil pH is 5.4.

Earth traps under the ecological and integrated farming system were placed. As model crops, Hordeum sativum, Triticum aestivum and Vicia faba with under seeding Medicago sativa were selected. Earth traps in each crop in two replicates were exposed. Length of parcels and their width was $10 \times 20 \mathrm{~m}$, within the each parcel, 2 earth traps were placed.

\section{Data analysis}

For data analysis, the following indexes were used:

a) faunistic similarity according to Jaccard $\left(I_{A}\right)$, reflects the consensus of species composition of two or more compared Zoocenoses. Its expression uses Jaccard number $\left(I_{A}\right)$ :

$$
I_{A}=\frac{s}{\left(s_{1}+s_{2}\right)-s} \cdot 100 \%
$$

where:

$s$ - the number of species present in two compared zoocenoses

$s_{1}-$ the number of species of one zoocenoses

$s_{2}$ - number of species of other zoocenoses

b) identity of dominance by Renkonnen $\left(I_{D}\right)$, expresses the similarity of communities, which can be recognized by life forms, ecological or taxonomic groups:

$$
R e=d_{1}+d_{2}+d_{3}+d_{i} \ldots
$$

where:

$d_{1}, d_{2^{\prime}} d_{3}$ and $d_{i}$ - the lowest dominance of groups, common to both zoocenoses

c) degree of diversity according to Shannon-Weaver (d) - adapted according Schwerdfeger (1978), expresses the ration of the number of species to the number of individuals. Indicator assesses the quantitative characteristic of every community:

$$
H^{\prime}=-\sum_{i=1}^{s}\left(\frac{N_{i}}{N}\right) \log _{n}\left(\frac{N_{i}}{N}\right)
$$

and after substituting:

$$
\stackrel{s}{H_{i=1}^{\prime}}=-\sum p_{i} \log _{n} p_{i}
$$

where:

$N$ - total number of individuals of studied zoocenoses

$p_{i}$ - the probability that one individual belongs to the species $\mathrm{i}$, while the $p_{i}=N_{i} / N$, ie the proportion of the number of individuals of any species and number of all individuals forming zoocenoses (Losos et al., 1984)

\section{Results and discussion}

The collections of epigeic material at the locality NitraDolná Malanta in the years 2013 and 2014 were made, under two farming systems, integrated one and ecological one. Earth traps were exposed in monocultures of grown crops Hordeum sativum, Triticum aestivum and Vicia faba with underseeding Medicago sativa. The total of 7,722 representatives of epigeic components of individuals (ex = exemplars), of which 3,367 ex were obtained under integrated farming and 4,355 ex under ecological farming (Table 1 and 2). It can be stated that the number of obtained individuals corresponds with methodology of collection. Common to both types of farming were 17 epigeic groups, of which 17 were detected in integrated and 19 in ecological 


\begin{tabular}{|c|c|c|c|c|c|c|c|c|c|c|c|c|c|c|c|c|c|c|}
\hline$\overbrace{}^{\circ}$ & $\begin{array}{l}\infty \\
\hat{\Lambda} \\
0 \\
0\end{array}$ & 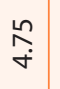 & $\underset{0}{\tilde{f}}$ & $\begin{array}{l}\stackrel{a}{1} \\
\hat{m}\end{array}$ & $\frac{m}{m}$ & i⿱口 & 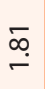 & 交 & $\stackrel{+}{\infty}$ & $\stackrel{\tilde{o}}{0}$ & $\begin{array}{c}\infty \\
\infty \\
\infty \\
0\end{array}$ & $\begin{array}{l}\text { fo } \\
0\end{array}$ & 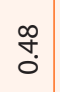 & $\begin{array}{l}\stackrel{a}{\infty} \\
0\end{array}$ & $\begin{array}{l}\mathcal{f} \\
0\end{array}$ & $\begin{array}{l}\hat{N} \\
\text { a }\end{array}$ & & ঃ \\
\hline & 怘 & $\stackrel{\circ}{\circ}$ & 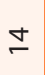 & 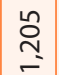 & $\stackrel{\mathfrak{Z}}{\mathcal{Y}}$ & 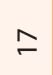 & 5 & $\stackrel{\Xi}{\sim}$ & $\widetilde{\sigma}$ & - & $\stackrel{\infty}{\sim}$ & $\stackrel{n}{\sim}$ & $\stackrel{\odot}{-}$ & ì & \pm & స్లి & & in \\
\hline
\end{tabular}

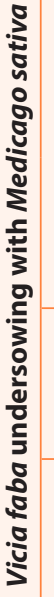

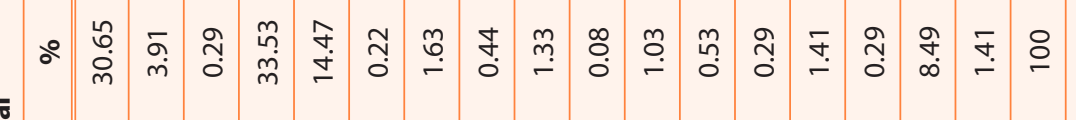
ชั

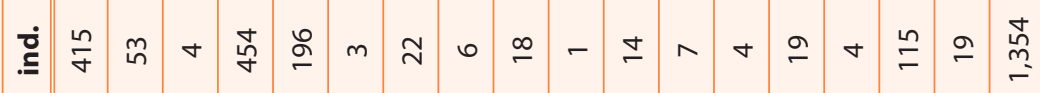

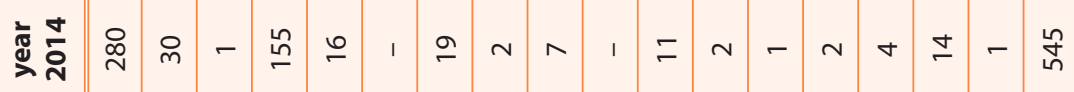

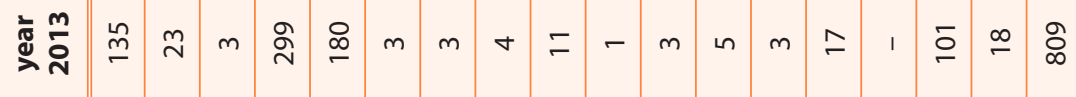

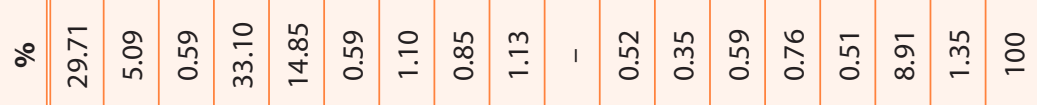

ฮั

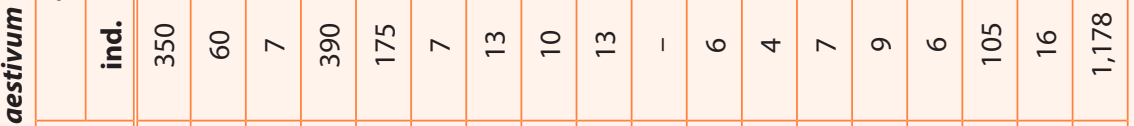

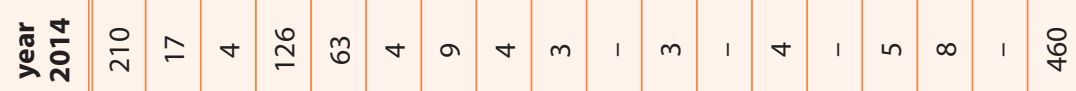

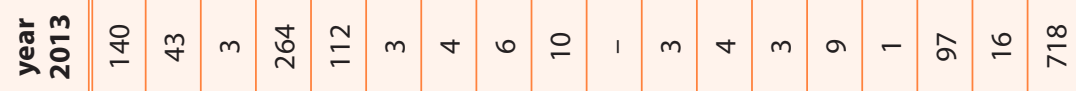

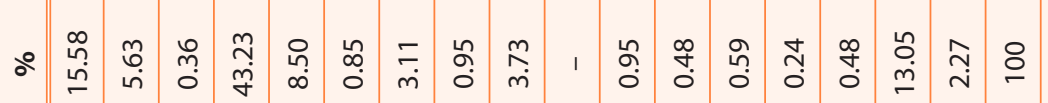

ฮั

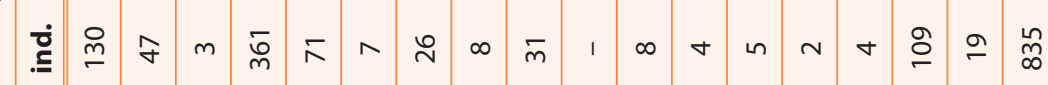

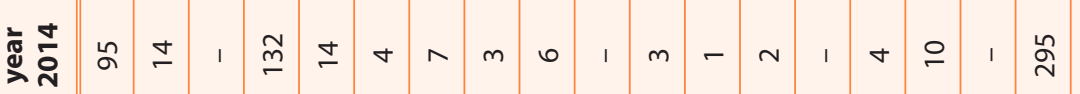

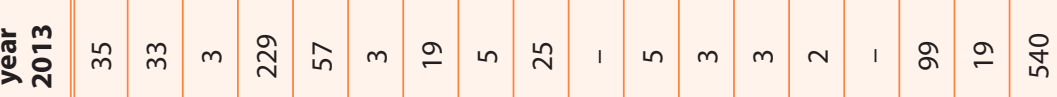




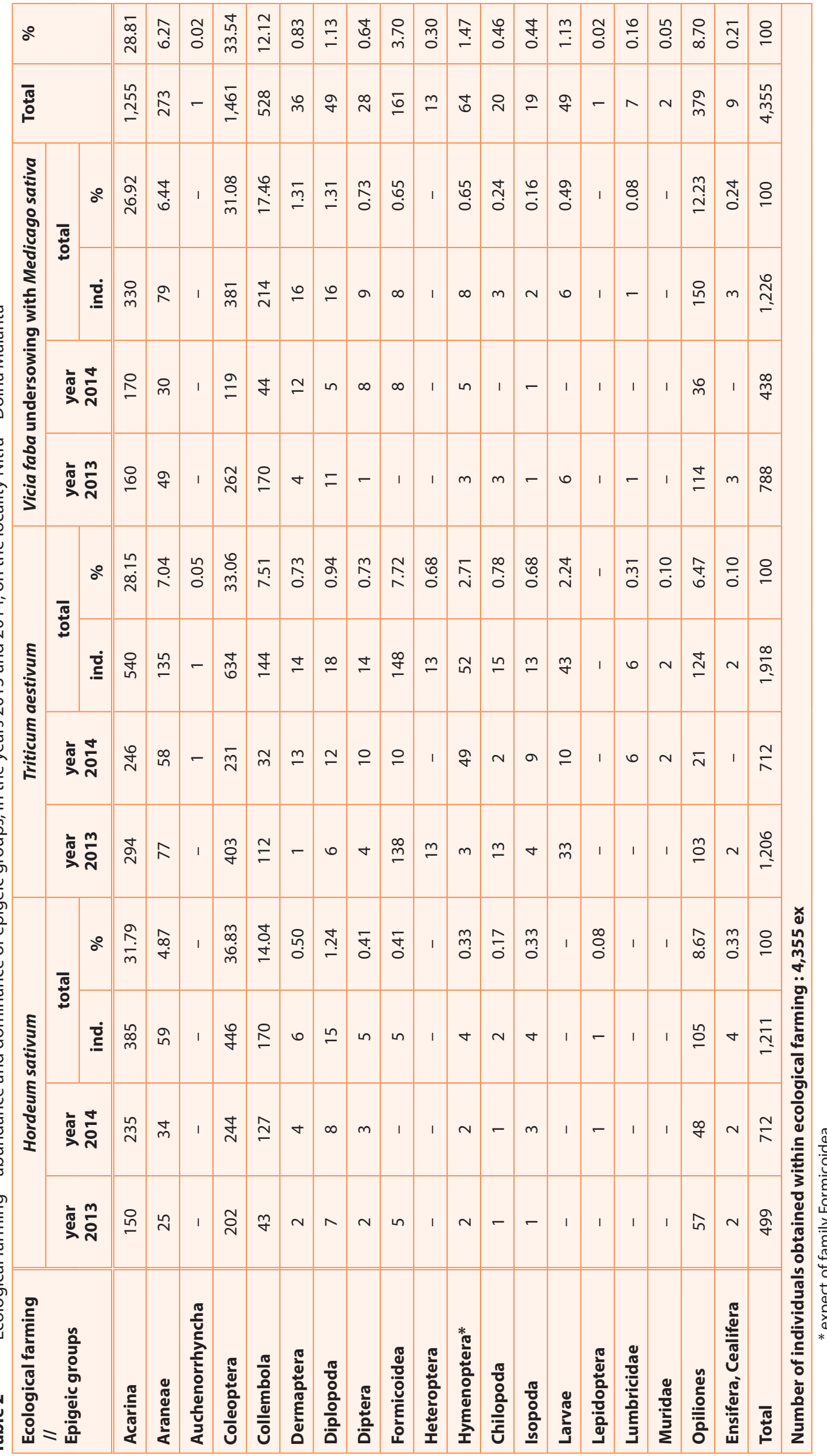


farming systems (Table 3). Almost all epigeic groups are among Invertebrates and only one group (family Muridae) was part of Vertebrates. Present epigeic groups represent a diversified component of soil fauna, due to large range of taxonomic groups and individual species with specific adaptations to soil habitats and different sensitivity to stress are useful in the study of various disturbance and impacts on the present soil environment (Porhajašová, 2011; Porhajašová et al., 2012). If we compare the found incidence of 19 epigeic groups within the monitored integrated and ecological farming with the number of occurring groups in nature reserves, where Porhajašová et al. (2010) in the Nature reserve Žitavský luh determined 30 epigeic groups and made clear that agroecosystems despite the poor anthropogenic interference do not provide ideal conditions for the existence and occurrence of epigeic groups. The principle that undistorted and balanced nature environment supported biodiversity of epigeic groups was confirmed.

In terms of assessment of abundance and dominance of individual epigeic groups for both types of farming (Table 1 and 2), Coleoptera can be evaluated as group with eudominant occurrence, where occurrence in the integrated farming 1,205 ex, with dominance of $35.79 \%$ and within the ecological farming 1,461 ex, with dominance $33.54 \%$ was found. Another epigeic group with significantly dominant representation was Acarina, which amounted in integrated farming 895 ex., with dominance of $26.58 \%$ and in ecological farming 1,255 ex, with dominance of $28.81 \%$. Almost identical eudominant representation showed Collembola within both types of farming, the value in integrated farming 442 ex, with dominance $13.13 \%$ and in ecological farming 528 ex, with dominance $12.12 \%$. The dominant occurrence showed Opiliones with occurrence in integrated farming 329 ex, with dominance $9.77 \%$ and in an ecological farming 379 ex, with dominance $8.70 \%$. The above findings confirm the view of Kromp and Steinber (1992), who considered epigeic groups Coleoptera, Collembola, Acarina and Araneida for groups typically dominant in agricoenose, but also greatly threatened due to intensive cultivation. Lenoir and Lennartsson (2010) found that excluding mentioned groups, Formicoidea had dominant occurrence in the agricoenose, but this is not confirmed. All groups in their opinion due to its high abundance and diversity significantly affect the maintenance of the natural balance and substance cycles and energy flow in ecosystems. Even the group Aranae with its occurrence confirmed the above findings. Authors Chabert and Beaufreton (2005), within their research found that the most sensitive to the application of insecticides and realized cultivation is arachnocenoses. Others present groups had significantly lower representation.

At the level of subdominant representation within ecological farming was Araneae with abundance 160 ex and dominance $4.75 \%$. Within the ecological farming at the level of subdominance was Formicoidea with abundance 161 ex and dominance $3.70 \%$, whose with their activities accelerate the degradation of plant debris, aerate the soil and improve its structure and quality. Lower incidence than 2\% recorded Diplopoda, Dermaptera, Chilopoda, Heteroptera and others. In this context it must be concluded that despite the lower representation their presence contributes to biodiversity of agroecosystems and meet the basic ecological functions. All epigeic groups, including less represented, are in ecosystems irreplaceable. E.g. Heteroptera participate in liquidation of acarinocenosis and thrips. Diplopoda act as saprophage, Dermaptera as saprophage to polyphagous insects. Unspecified developmental stages of individuals, which we have marked as larvae were also present. The present groups contribute to the overall diversification of community in the whole ecosystem and in agrarian country.

In terms of impact assessment of crop on incidence of epigeon can be considered for the most appropriate within the integrated farming the vegetation of Vicia faba with Medicago sativa (1,354 ex), then monoculture Triticum aestivum $(1,178$ ex) and based on the values from the table 1 acted as the least suitable crop Hordeum sativum (835 ex). Within the ecological farming, the most suitable conditions were provided by Triticum aestivum (1,918 ex), then Vicia faba with Meidcago sativa (1,226 ex) and for Hordeum sativum has been found the lowest value (1,211 ex). It follows that thicksown cereals do not provide the most suitable conditions for the existence of epigeic groups. Since this is species

Table 3 Summary of epigeic groups on the part of dominance and calculation of indexes

\begin{tabular}{|c|c|c|}
\hline & Integrated farming & Ecological farming \\
\hline Number of epigeic groups & 17 & 19 \\
\hline \multicolumn{3}{|c|}{ Representation of epigeic groups in terms of dominance } \\
\hline 1. Eudominant representation: $>10 \%$ & 3 & 3 \\
\hline 2. Dominant representation: $5-10 \%$ & 1 & 2 \\
\hline 3. Subdominant representation: $2-5 \%$ & 1 & 1 \\
\hline 4. Recedent repersentation: $1-2 \%$ & 3 & 3 \\
\hline 5. Subrecedent representation: $<1 \%$ & 9 & 10 \\
\hline \multicolumn{3}{|c|}{ Calculated indexes } \\
\hline Faunistic similarity & \multicolumn{2}{|c|}{$89.47 \%$} \\
\hline Identity of dominance & \multicolumn{2}{|c|}{$94.83 \%$} \\
\hline Index of diversity & 1.8009 & 1.7585 \\
\hline
\end{tabular}


whose habitat is soil (moisture of substrate), or many species are heliophobe and prefer shading, there is the assumption that Vicia faba with Medicago sativa meets the demands of present epigeic groups.

If we evaluated the basic cenotic characteristics such as faunistic similarity, identity and dominance diversity index with compared systems of farming there were no significant differences found (Table 3). Faunistic similarity when comparing Zoocoenoses in both types of farming achieved a favourable value of $89.47 \%$, which can be compared with the value calculated in the natural environment of nature reserve (Porhajašová et al., 2010), which ranged from 72 to $84 \%$. Value of dominant identity was $94.83 \%$, which again confirmed similarity of Zoocoenoses within habitats with application of all biotic and abiotic factors. Diversity index assessed statistical - ecological richness, species diversity and uniformity of distribution of communities in ecosystem. Calculated index value of diversity was 1.8009 in integrated farming and 1.7585 under ecological farming, it is an evidence of balanced and stable ecosystem with good homeostatic abilities. Undisturbed environment provides better conditions after the topical and trophic site than ecosystems significantly affected by human activity (Porhajašová et al., 2009, Baranová et al., 2013). We can conclude that both types of farming reflect the suitability of environment and its priority aim is to preserve biological diversity in agroecosystems, with minimal pollution of environment.

\section{Acknowledgements}

Authors wish to thank Agency VEGA for financial support for solving the research project, in which originated presented contribution. This paper was supported by project: VEGA 1/0513/12, VEGA 1/0124/13 and VEGA 1/0816/11.

\section{References}

BARANOVÁ, B. - FAZEKAŠOVÁ, D. - JÁSZAY, T. - MANKO, P. 2013. Ground beetle (Coleoptera: Carabidae) community of arable land with different crops. In Folia faunistica Slovaca, vol. 18, 2013, no. 1, p. 21-29. ISSN 1335-7522.

BUCHAR, J. - DUCHÁČ, V. - HŮRKA, K. - LELLÁK, J. 1995. Klíč k určování bezobratlých. Praha : Scientia. $159 \mathrm{p}$.

CHABERT, A. - BEAUFRETON, CH. 2005. Impact de Quelques culturales sur les Carabes, Araignees, Staphylins. In AFPP $-7^{\mathrm{e}}$ "Conference Internationale sur les ravageurs en agriclture Montpellier", 2007. pp. 1-10.

KROMP, B. - STEINBERG, K. H. 1992. Grassy Field Margin and Arthropod Diversity - A Case Study ground Beetle and Spiders in Eastern Austria Coleoptera, Carabidae, Arachnidae, Aranei, Opiliones). In Agriculture, ecosystems and environment, vol. 40, 1992, no. 1-4. 116 pp.

LACKO-BARTOŠOVÁ, M. - CAGÁŇ, L.. - ČUBOŇ, J. et al. 2005. Udržatel'né a ekologické polnohospodárstvo. Nitra : SPU, 2005. 571 s. ISBN 80-8069-556-3.

LENOIR, L. - LENNARTSSON, T. 2010. Effects of timing of grazing on arthropod communities in semi-natural grasslands. In Journal of Insect Science, vol. 10, 2010, pp. 33-42. ISSN 1536-2442.
LOSOS, B. - GULIČKA, J. - LELLÁK, J. - PELIKÁN, J. 1984. Ekologie živočichů. Praha: SPN, 1. vydanie, 1984, 300 pp.

PAOLETTI, A. 1999. Ivertebrate biodiversity as bioindicators of sustainable landscape. Elsevier Science B. Amsterdam. 1999, 446 pp.

PETŘVALSKÝ, V. - PORHAJAŠOVÁ, J. - PETERKOVÁ, V. 2003. Výskyt bystruškovitých (Carabidae, Coleoptera) $\mathrm{v}$ pôde $\mathrm{s}$ rozdielnym typom hospodárenia. In Agriculture, roč. 49, 2003, č. 12, s. 619-624. ISSN 0551-3677.

PORHAJAŠOVÁ, J. - PETŘVALSKÝ, V. - URMINSKÁ, J. - POSPIŠIL, R. 2005. Vplyv množstva organickej hmoty v pôde na výskyt epigeónu a populácií bystruškovitých (Carabidae, Coleoptera). In Acta hortic. et regiotec, roč. 8, 2005. č. 2, s. 42-46. ISSN 1335-2563.

PORHAJAŠOVÁ, J. - PETŘVALSKÝ, V. - ŠUSTEK, Z. et al. 2008. Long-termed changes in ground beetle (Coleoptera: Carabidae) assemblages in a field treated by organic fertilizers. In Biology. Section Zoology, vol. 63, 2008, no. 6, pp. 1184-1195. ISSN 00063088 (1336-9563).

PORHAJAŠOVÁ, J. - URMINSKÁ, J. - NOSKOVIČ, J. - ONDRIŠÍK, P. - ŠUSTEK, Z. 2009. Biodiverzita epigeických skupín Prírodnej rezervácie Alúvium Žitavy. In Acta fytotechnica et zootechnica, roč. 12, 2009, č. 2, s. 52-57. ISSN 1335-258X.

PORHAJAŠOVÁ, J. - NOSKOVIČ, J. - URMINSKÁ, J. - ONDRIŠÍK, P. 2010. Význam prírodných rezervácií Žitavský luh a Alúvium Žitavy z hladiska biodiverzity epigeických skupín. In Acta horticulturae et regiotecturae, roč. 13, 2010, č. 2, s. 32-37. ISSN 1335-2563.

PORHAJAŠOVÁ, J. 2011. Vplyv aplikácie organických hnojív na priestorovú štruktúru bezstavovcov s dôrazom na čelad' Carabidae. In Habilitačná práca, 2011, $133 \mathrm{~s}$.

PORHAJAŠOVÁ, J. - NOSKOVIČ, J. - BABOŠOVÁ, M. - RAKOVSKÁ, A. 2012. Biodiverzita epigeických skupín v podmienkach pestovania rýchlorastúcej vŕby košikárskej (Salix viminalis L.). In Acta Universitatis Prešoviensis, roč. 54, 2012, č. 7, s. 5-13. ISSN 1338-080X. SCHWERDTFEGER, F. 1978. Lehrbuch der Tierőkologie. Verlag Paul Parey : Hamburg und Berlin, 1978. 384 p. ISBN 3-490-07718-0.

STAŠIOV, S. - TROJÁK, M. - KERTYS, Š. - URBLÍK, P. - SVITOK, M. 2012. Spoločenstvá stonôžok (Chilopoda) v historických štruktúrach pol'nohospodárskej krajiny. In Folia faunistica Slovaca, roč. 17, 2012, č. 2, s. 143-149. ISSN 1335-7522.

ŠUSTEK, Z. 1983. The comparison of the Carabidae and Staphylinidae (Insecta, Coleoptera) in the selected geobiocenoses fo Pavlovské kopce hills during the years 1971 - 1981. In Biológia (Bratislava), vol. 38, 1983, no. 2, pp. 105-115.

VICIAN, V. - STAŠIOV, S. - KOČíK, K. - HAZUCHOVÁ, L. 2007. Štruktúra chrobákov (Carabidae, Coleoptera) na rôzne obhospodarovaných pol'nohospodárskych plochách. In Zborník z konferencie „Vplyvy foriem obhospodarovania pol'nohospodárskej krajiny na základné zložky agroekosystémov vo vztahu k optimalizácii využívania krajiny“. Vyd. Čižmárová-Partner, 2007. s. 67 - 77. ISBN 978-80-89183-35-7.

VICIAN, V. - STAŠIOV, S. - KOČÍK, K. - HAZUCHOVÁ, L. 2011. Štruktúra spoločenstiev bystruškovitých (Coleoptera: Carabidae) na rôzne obhospodarovaných polnohospodárskych plochách v oblasti Podpol'ania a ich bioindikácia. In Acta Facultatis Ecologiae, 2011, č. 24-25, s. 123-131. ISSN 1336-300X. 